\title{
Polyphenolic Compounds and Free Radical Scavenging Activity in Eight Lamiaceae Herbs of Manipur
}

\author{
Sandhyarani D. KHOMDRAM, Potsangbam K. SINGH \\ Manipur University, Centre for Advanced Study in Life Sciences, Canchipur, Imphal -795003, \\ India; sandhyakhomdram@gmail.com,potsangbam031@gmail.com
}

\begin{abstract}
Eight plants of Lamiaceae under subfamily Nepetoideae found in Manipur, India were selected for estimation of their polyphenolic compounds and free radical scavenging activity which is expressed on dry weight basis. In this present study, the total phenol and flavonoid contents as well as the free radical scavenging activity were studied using spectrophotometric method. The total phenol content was determined based on Folin-Ciocalteau reagent, flavonoid was determined by aluminium chloride spectrophotometric method and tannin by Folin Dennis Method. The free radical scavenging activity was determined by using DPPH radical which is expressed as IC $(\mu \mathrm{g} / \mathrm{ml})$. The total phenolic content varied from $21.39 \pm 0.927$ to $46.28 \pm 0.543 \mathrm{mg} / \mathrm{g}$, flavonoids content in the selected samples varied from $13.30 \pm 0.684$ to $26.03 \pm 0.217 \mathrm{mg} / \mathrm{g}$ and tannin content varied from $8.72 \pm 0.160$ to $17.04 \pm 0.206 \mathrm{mg} / \mathrm{g}$. The free radical scavenging activity among the selected samples varied from $11.67 \pm 0.221$ to $38.29 \pm 0.532 \mu \mathrm{g} / \mathrm{ml}$. The correlation between the free radical scavenging activity with total phenol content $\left(R^{2}=0.511\right)$, with flavonoids $\left(R^{2}=0.241\right)$ and with tannin $\left(R^{2}=0.690\right)$ was calculated and maximum correlation value was found between tannin content and the free radical scavenging activity of the plant samples. The result supports that tannins were more responsible for free radical scavenging activity in the presently selected plants.
\end{abstract}

Keywords: antioxidant, flavonoids, $\mathrm{IC}_{50}$, Indo-Myanmar hotspot, Nepetoideae, tannin

\section{Introduction}

Polyphenols are a group of secondary metabolites involved in the $\mathrm{H}_{2} \mathrm{O}_{2}$ scavenging in plant cells. Interest in plant materials rich in polyphenolic compounds are on the increase due to their high antioxidant potency, which may offer protection against cancer, through the inhibition of oxidative damage, known to be a potential cause of mutation. Free radicals cause oxidative damage to lipids, proteins, and nucleic acids (Shui and Leong, 2004). The antioxidative property of polyphenols is a predominant feature of their radical-scavenging capacity (Yang et al., 2001; Cotelle, 2001; Facino et al., 1990). They possess ideal structural chemistry for radical scavenging activity and are more effective than tocopherol and ascorbate (Pandhair and Sekhon, 2006). In the aerobes, due to large generation of reactive oxygen species such as superoxide radical, hydrogen peroxide, and hydroxyl radical leads to severe effects on the cardiovascular system either through lipid peroxidation or vasoconstriction and other ailments such as inflammation, cancer, diabetes mellitus etc (Lachance $e t$ al., 2001; Nickavar et al., 2007).

Phenolic acids, flavonoids and tannins are the most commonly found polyphenolic compounds in plant extracts (Wolfe et al., 2003; Naik et al., 2006). Flavonoids are 15 -carbon compounds generally distributed throughout the plant kingdom (Harborne, 1988). Flavonoids and many other phenolic compounds of plant origin have been reported as scavengers of reactive oxygen species (ROS), and are viewed as promising therapeutic drugs for free radical pathologies (Parshad et al., 1998; Chang et al., 2007). Tannins are naturally occurring, high molecular weight polyphenols which can be divided into hydrolysable tannins and condensed tannins. Tannins are the most abundant antioxidants in the human diet and they exhibit many biologically important functions which include protection against oxidative stress and degenerative diseases (Atanassova and Christova-Bagdassarian, 2009). The oxidation inhibiting activities of tannins have been known for a long time (Edeoga et al., 2006).

The family Lamiaceae is represented by about 236 genera and 7172 species in the world (Harley et al., 2004). It is a well known fact that many members under this family are useful economically for medicinal, culinary, ornamental and various commercial utilizations. Many plants, especially those belonging to the Lamiaceae family show strong antioxidant activity (Marinova and Yanishlieva, 1997; Hirasa and Takemasa, 1998; Triantaphyllou et al., 2001). Thus, members of the family are very important due to their medicinal and aromatic properties leading to production of the herbal products and food supplements.

The state of Manipur which extends between $23^{\circ} 59^{\prime} \mathrm{N}-25^{\circ} 47^{\prime} \mathrm{N}$ and between $92^{\circ} 59^{\prime} \mathrm{E}-94^{\circ} 46^{\prime} \mathrm{E}$ with total geographical area of $22,327 \mathrm{~km}^{2}$ lies in the NorthEastern part of India falls under Indo-Myanmar hotspot regions of the world (Meyers et al., 2000) with extraordi- 
narily rich flora. A total of 39 genera with 110 species of Lamiaceae are distributed all over the state which includes some endemic plants. Among these species, some are found in cultivated form only and some are found in wild forms. Measurement of the polyphenols and free radical scavenging activity of herbs has become important tools for the understanding of the relative importance of plant species especially from the health point of view (Chang et al., 2007). This paper provides an evaluation and comparison of the polyphenolic contents and their relative free radical scavenging activity of the eight selected taxa of $\mathrm{La}$ miaceae.

\section{Materials and methods}

\section{Plant material collection}

The seeds of selected taxa (i.e. Elsholtzia blanda Benth., E. communis (Coll. and Hemsl.) Diels var. purple flower, E. communis (Coll. and Hemsl.) Diels var. white flower, E. stachyodes (Link) Wu, Hyptis suaveolens Poit, Ocimum americanum L., O. basilicum L. and Perilla frutescens L.) Tab. 1 under the subfamily Nepetoideae of family Lamiaceae were collected locally and planted in experimental fields for this study. All the selected taxa are used as culinary herbs in Manipur and are cultivated, with the exception of $H$. suaveolens, which has high medicinal values and is widespread as a noxious weed (Devi et al., 2008). The aerial parts of these plants were collected just before the flowering time. The collected samples were shade dried and ground into powder form by a grinder. Specimens were identified and the vouchers were deposited at the Manipur University Museum of Plants (MUMPS), Department of Life Sciences, Manipur University.

Tab. 1. Eight selected species of Lamiaceae of Manipur with their local names and voucher numbers

\begin{tabular}{ccc}
\hline Species & Local Name & Voucher No. \\
\hline Elsholtzia blanda Benth. & Kanghuman & 004302 \\
$\begin{array}{c}\text { E. communis (Coll. and Hemsl.) } \\
\text { Diels var. purple flower }\end{array}$ & Lomba & 004328 \\
$\begin{array}{c}\text { E. communis (Coll. and Hemsl.) } \\
\text { Diels var. white flower }\end{array}$ & Lomba & 004301 \\
E. stachyodes (Link) Wu & Tekta & 004303 \\
Hyptis suaveolens Poit. & Tukma & 004311 \\
Ocimum americanum L. & Mayangba & 004313 \\
O. basilicum L. & Naoseklei & 004312 \\
Perilla frutescens L. & Thoiding Angouba & 004309 \\
\hline
\end{tabular}

\section{Extraction}

\section{Extraction method for Total Phenolics and Tannins}

Total phenol content and tannin were estimated by using Folin-Ciocalteau reagent (FCR) and Folin Dennis method respectively (Thimmaiah, 1999). One hundred milligram of the ground powder of the plant samples were weighed and kept in magnetic stirrer for $3 \mathrm{~h}$ after adding $10 \mathrm{ml}$ of $80 \%$ ethanol. The extracts were centrifuged for 15 min at 10,000 rpm. The supernatants were collected and stored for analyzing total phenol and tannin contents.

\section{Extraction method for flavonoids}

Hundred milligrams of the powdered samples were weighed and mixed with $10 \mathrm{ml}$ of $80 \%$ methanol by intermittent maceration for $48 \mathrm{~h}$. The solvents were evaporated and reduced up to $5 \mathrm{ml}$ at room temperature. This extract was stored for the estimation of flavonoids contents. Aluminium Chloride spectrophotometric method was used for flavonoids determination (Chang et al., 2002) with slight modification.

\section{Extraction method for free radical scavenging activity}

Plant extraction was done by slight modification of method adopted by Yang et al. (2007). From the dried powdered samples, $3 \mathrm{~g}$ were weighed and put into $100 \mathrm{ml}$ flasks. Each flask was added with $50 \mathrm{ml}$ of $80 \%$ methanol. After one week of storage at room temperature the supernatants were filtered and these filtered extracts were dried at room temperature $\left(30^{\circ} \mathrm{C}\right)$. The dried samples were then weighed. The extracted samples were then dissolved in 10 $\mathrm{ml}$ methanol and stored in refrigerator for further experiments.

\section{Estimation of total phenolics}

From the supernatants of phenolic extracts, $1 \mathrm{ml}$ of each sample were collected then evaporated in a petriplate to dryness. Then the dried residue is dissolved in $1 \mathrm{ml}$ of distil water. $100 \mu$ lof the dissolved residue was taken and its volume was made up to $3 \mathrm{ml}$ with distil water. In the test tubes containing test samples, $0.5 \mathrm{ml}$ of folin-ciocalteau reagent was added. Then after $2 \mathrm{~min}, 20 \%$ of $\mathrm{Na}_{2} \mathrm{CO}_{3}$ were added and mixed thoroughly. The contents were kept in a boiling water bath for about $1 \mathrm{~min}$. Then the test tubes were cooled in running tap water and the absorbances of the blue coloured complex were taken against blank at $650 \mathrm{~nm}$ with the help of UV-VIS Double Beam Spectrophotometer Version 6.51. The total phenol content was calculated and expressed in $\mathrm{mg} / \mathrm{g}$ using a standard curve prepared from catechol.

\section{Estimation of flavonoids}

From the supernatants of flavonoids extract, $100 \mu \mathrm{l}$ of the supernatant was taken and it was added with $0.1 \mathrm{ml}$ of Aluminium chloride (10\%), $0.1 \mathrm{ml}$ of potassium acetate $(1 \mathrm{M})$ and $2.7 \mathrm{ml}$ of distil water to make up volume to 3 $\mathrm{ml}$. The reaction mixture was kept at room temperature for $30 \mathrm{~min}$. The absorbance was measured at $415 \mathrm{~nm}$ using UV-VIS Double Beam Spectrophotometer Version 6.51. The calibration curve was prepared using different concentrations of quercetin which is expressed in $\mathrm{mg} / \mathrm{gm}$ dry weight. 
110

\section{Estimation of tannin}

From the supernatants of tannin extracts, $100 \mu \mathrm{l}$ of aliquot of each sample was taken and $7.5 \mathrm{ml}$ of distil water were added. After that, $0.5 \mathrm{ml}$ of Folin Denis Reagent (FDR) followed by $1 \mathrm{ml}$ of $35 \% \mathrm{Na}_{2} \mathrm{CO}_{3}$ was added The final volume was made up to $10 \mathrm{ml}$ with distil water. The blue colour appeared was measured at $700 \mathrm{~nm}$ by using UV-VIS Double Beam Spectrophotometer Version 6.51. The calibration curve was prepared using tannic acid expressed in $\mathrm{mg} / \mathrm{gm}$ dry weight.

\section{Estimation of free radical scavenging activity by DPPH} method

Free radical scavenging activity was determined by using DPPH radical (Dudonne et al., 2009). The DPPH radical has been widely used to investigate the scavenging activities where the DPPH radical is scavenged by antioxidants through the donation of a hydrogen atom forming the reduced DPPH-H. The DPPH. solution in methanol $\left(6 \times 10^{-5} \mathrm{M}\right)$ was freshly prepared, where $3 \mathrm{ml}$ of this solution was mixed with $100 \mu \mathrm{l}$ of methanolic plant extracts $(3-50 \mu \mathrm{g} / \mathrm{ml})$. The samples were incubated for $20 \mathrm{~min}$ at $37^{\circ} \mathrm{C}$ in a water bath, and then the decrease in absorbance at $515 \mathrm{~nm}$ was measured $\left(A_{F}\right)$ in an UV-VIS Double Beam Spectrophotometer Version 6.51. A blank sample containing $100 \mu \mathrm{l}$ of methanol in DPPH. solution was freshly prepared and its absorbance was measured $\left(A_{B}\right)$. The experiment was carried out in triplicate. Radical scavenging activity was calculated using the formula given below:

$$
\% \text { inhibition of DPPH }=\left[\frac{A_{B}-A_{E}}{A_{B}}\right] \times 100
$$

A percent inhibition versus concentration curve was plotted and the concentration of sample required for 50\% inhibition was determined and represented as $\mathrm{IC}_{50}$ for each of test solution which is expressed as $\mu \mathrm{g} / \mathrm{ml}$.

\section{Statistical analysis}

Each parameter which are under consideration was carried out three times from which the mean values and their respective standard error mean (SEM) were calculated by using Microsoft Excel-2007. Significant differences of the data among the parameters were calculated by performing ANOVA test with the help of SPSS (9) and means were compared by least significant difference (LSD). Differences at $\mathrm{P}<0.05$ were considered to be significant. Correlation analyses of free radical scavenging activity $(\mathrm{Y})$ versus the total phenolic content, flavonoids and tannin $(\mathrm{X})$ were also carried out by using Microsoft Excel-2007.

\section{Results and discussion}

Over the past few years, investigations for phenolics compounds in medicinal herbs have gained importance due to their high antioxidative properties (Zhu et al., 2004). Tab. 2 presented the total phenol, flavonoid and tan- nin content of the selected plants under Lamiaceae which is expressed on dry weight basis as $\mathrm{mg} / \mathrm{g}$. The amount of total phenols varied in different plants and ranged from 21.39 to 46.28 with maximum value in Elsholtzia blanda (46.28 \pm 0.543$)$ and minimum in E. communis var. purple flower (21.39 \pm 0.927$)$. Hakkim et al. (2008) reported the variable range of total phenolic content on dry weight basis as $42.1 \pm 3.1$ in $O$. selloi, $123.1 \pm 2.3$ in Ocimum americanum and $168.2 \pm 3.2 \mathrm{mg} \mathrm{GA} / \mathrm{g}$ in $O$. gratissimum. In different parts of three Coleus species, the total phenol content ranged from 16.32 to $62.12 \mathrm{mg} / \mathrm{g}$ FW (Fresh Weight) (Rasineni et al., 2008).

Tab. 2. Polyphenolic Contents (mg/g DW (Dry Weight) \pm SEM) in mature aerial parts of Lamiaceae plants $(n=3)$

\begin{tabular}{cccc}
\hline Species & Total Phenol & Flavonoid & Tannin \\
\hline Elsholtzia blanda & $46.28 \pm 0.543$ & $23.35^{\mathrm{a}} \pm 0.217$ & $17.04 \pm 0.206$ \\
$\begin{array}{c}\text { E. communis var. } \\
\text { purple flower }\end{array}$ & $21.39^{\mathrm{a}} \pm 0.927$ & $16.86^{\mathrm{b}, \mathrm{c}} \pm 0.976$ & $8.72 \pm 0.160$ \\
$\begin{array}{c}\text { E. communis var. } \\
\text { white flower }\end{array}$ & $22.52^{\mathrm{a}, \mathrm{b}} \pm 0.591$ & $17.45^{\mathrm{c}} \pm 0.369$ & $10.87^{\mathrm{a}} \pm 0.167$ \\
\hline E. stachyodes & $32.07 \pm 0.566$ & $22.00^{\mathrm{a}} \pm 0.856$ & $14.52 \pm 0.201$ \\
Hyptis suaveolens & $32.07 \pm 0.363$ & $16.22^{\mathrm{b}} \pm 0.684$ & $15.39^{\mathrm{b}} \pm 0.138$ \\
O. americanum & $26.15 \pm 0.808$ & $15.66^{\mathrm{b}} \pm 0.215$ & $9.47 \pm 0.076$ \\
\hline O. basilicum & $39.31 \pm 0.439$ & $26.03 \pm 0.217$ & $15.13^{\mathrm{b}} \pm 0.187$ \\
\hline Perilla frutescens & $23.80^{\mathrm{b}} \pm 0.363$ & $13.30 \pm 0.684$ & $10.53^{\mathrm{a}} \pm 0.138$ \\
\hline
\end{tabular}

Note: Different letters between species denote significant differences (LSD test, $\mathrm{P}<0.05$ )

The flavonoid content in the selected species ranged from $13.30 \pm 0.684$ (Perilla frutescens) to $26.03 \pm 0.217$ ( $O$. basilicum) (Tab. 2). In five Salvia species, Nickavar et al. (2007) reported the total flavonoid content which ranged from $8.58 \pm 0.99$ to $53.16 \pm 1.95 \mathrm{mg} / \mathrm{g}$ DW due to the difference in species. Thus, the different values of flavonoids among the selected plants and also with other plants will be due to belonging to different taxa. Flavonoids exhibit inhibition of mutagenicity induced by chemical mutagens and have anticarcinogenic, antioxidant and anti-inflammatory activities (Miyazawa et al., 2000).

In the selected eight plants of Lamiaceae, the tannin content was found maximum in E. blanda $(17.04 \pm 0.206)$ and minimum in E. communis var. purple flower $(8.72 \pm 0.160)$ (Tab. 2). Tannin content among different tissues of three species of Coleus was found to be $0.085-0.210 \mathrm{mg} / \mathrm{g} \mathrm{FW}$ (Rasineni et al., 2008). Recent studies have demonstrated that, low dosages of tannins $(0.15-0.2 \%)$ in the diet can be beneficial to human health and will create a more astringent feel to the taste, although at higher concentration, they inhibit the digestive enzymes and reduce the bioavailability of iron and vitamin $B_{12}$ (King-Thom et al., 1998). Tannins have shown potential antiviral, antibacterial and antiparasitic effects (Akiyama et al., 2001; Lu et al., 2004). In the past few years tannins have also been studied for their potential effects against cancer through different mechanisms (Yang et al., 2000; Tanimura et al., 2005). 


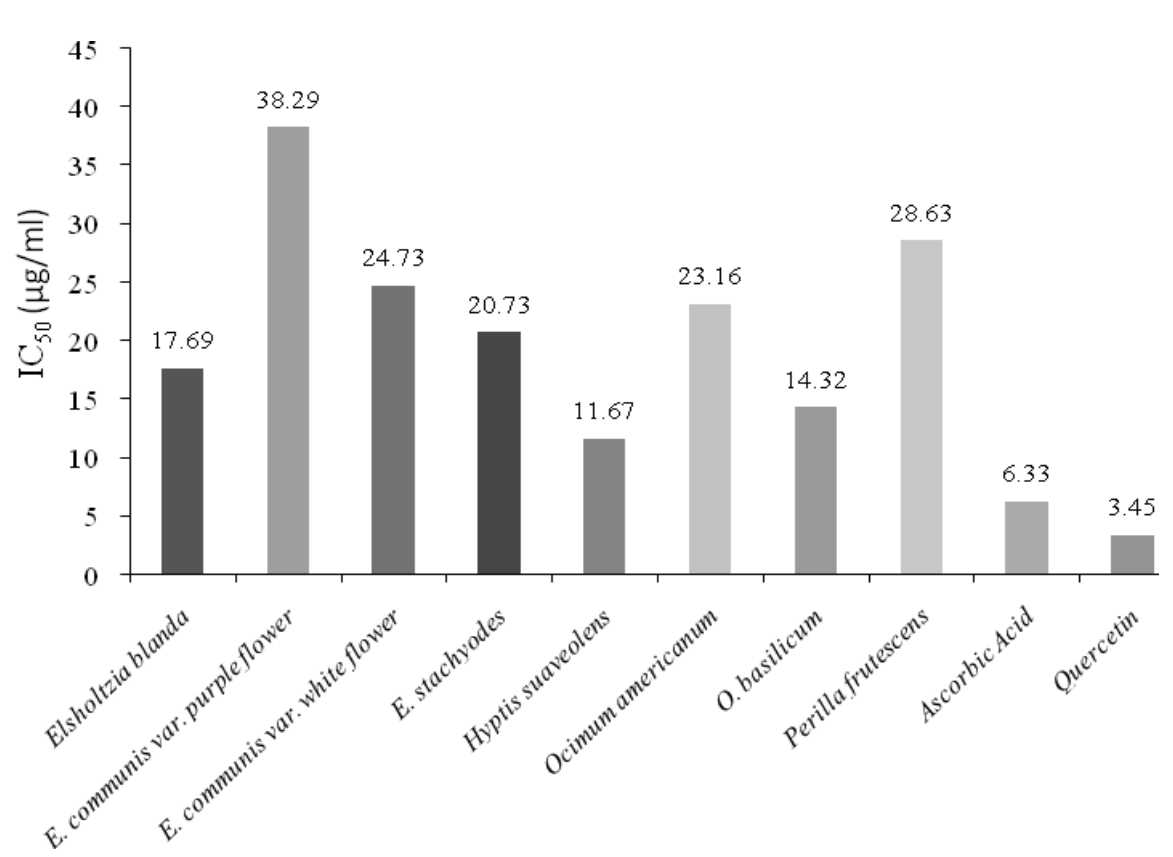

Fig.1. Free radical scavenging activity of the eight Lamiaceae plants of Manipur

Fig. 1 presents the free radical scavenging activity of the selected plants under Lamiaceae found in Manipur which is expressed as $\mathrm{IC}_{50}(\mu \mathrm{g} / \mathrm{ml})$. The maximum free radical scavenging activity was found in Hyptis suaveolens $(11.67 \pm 0.221)$ and minimum in E. communis var. purple flower $(38.29 \pm 0.532)$ with more free radical scavenging activity in $H$. suaveolens as lesser is the $\mathrm{IC}_{50}$ of the sample, more is the free radical scavenging activity and vice versa. The $\mathrm{IC}_{50}$ of five Salvia species ranged from 23.53 to 129 $\mu \mathrm{g} / \mathrm{ml}$ (Nickavar et al., 2007). The greater the free radical scavenging activity, the greater the antioxidant property as an antioxidant may be defined as any substance that when present at low concentrations compared with those of the

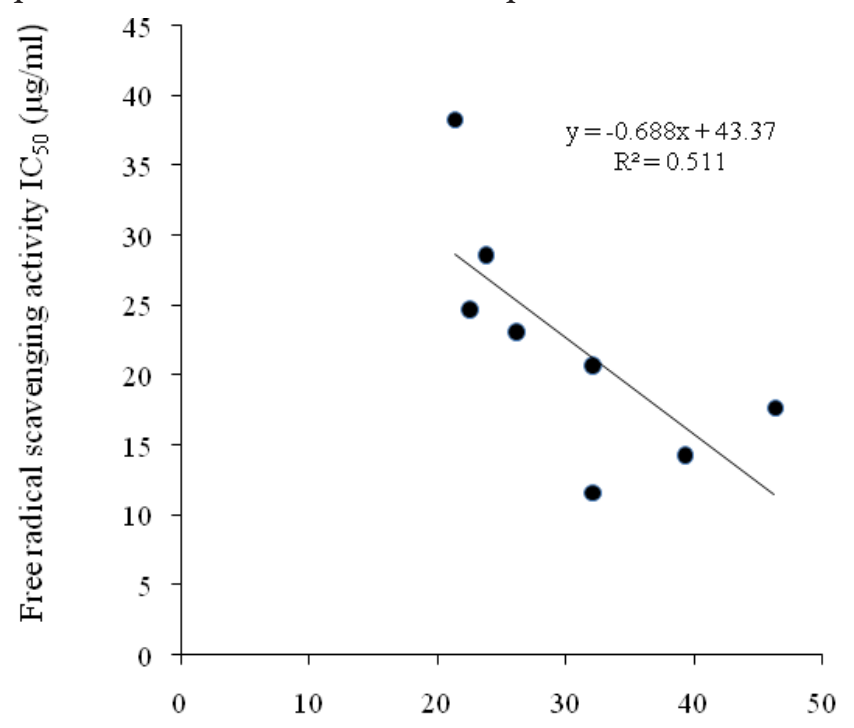

Total phenolic content (mg/g DW)

Fig. 2. Correlation of free radical scavenging activity $(Y)$ versus total phenolic content $(\mathrm{X})$ of eight Lamiaceae plants of Manipur oxidative substrate significantly delays or inhibit that substrate (Antolovich et al., 2002).

It has been reported that the antioxidant activity of many compounds of botanical origin is proportional to antioxidant content suggesting a correlation between total phenolics and antioxidant activity (Rice-Evans et al., 1997; Veglioglu et al., 1998). The correlation between free radical scavenging $(Y)$ and total phenol content $(X)$ of eight Lamiaceae plants found in Manipur had a correlation coefficient of $\mathrm{R}^{2}=0.511$ (Fig. 2). It suggests that $51 \%$ of the free radical scavenging of these eight Lamiaceae plants is contributed by phenolic compounds. The antioxidative activity of polyphenols is generally ascribed to

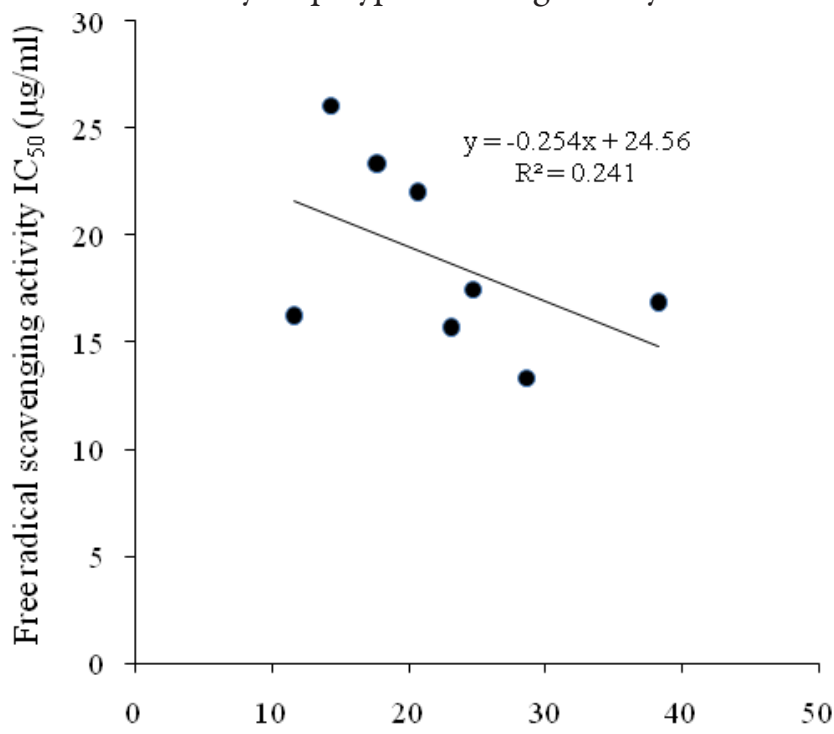

Flavonoid content (mg/g DW)

Fig. 3. Correlation of free radical scavenging activity $(\mathrm{Y})$ versus flavonoid content $(\mathrm{X})$ of eight Lamiaceae plants of Manipur 


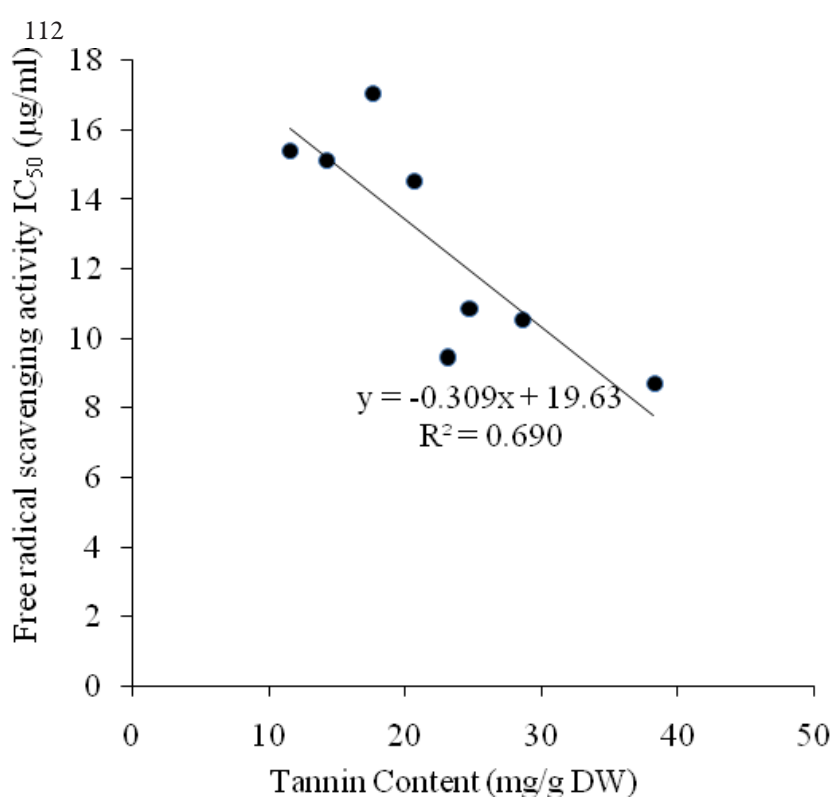

Fig. 4. Correlation of free radical scavenging activity $(\mathrm{Y})$ versus tannin content $(\mathrm{X})$ of eight Lamiaceae plants of Manipur

their hydroxyl groups (Chen and Ho, 1997). The remaining $49 \%$ of free radical scavenging activity may come from the presence of other active components like essential oils, carotenoids, vitamins and other glycosides. Among the phenolic compounds, the contribution of flavonoids as free radical scavenging activity as compared to with tannin in these eight selected Lamiaceae plants is found to be less. The correlation between flavonoids $(\mathrm{X})$ with free radical scavenging activity $(\mathrm{Y})$ is found to have a correlation coefficient of $\mathrm{R}^{2}=0.241$ (Fig. 3) and with $\operatorname{tannins}(\mathrm{X})$ and free radical scavenging activity $(\mathrm{Y})$ is found to have a correlation coefficient of $\mathrm{R}^{2}=0.690$ (Fig. 4). In this case also, among the phenolic compounds also, the contribution of flavonoids is found to be $24.1 \%$ and tannin is found to be $69 \%$ in these eight selected plants of Lamiaceae found in Manipur. The present study shows that among the phenolic compounds also, tannins show high free radical scavenging activity and are good antioxidants which are also found to used as anti carcinogenic, anti mutagenic and in treatment of cancer patients (Ramakrishnan et al., 2006).

\section{Conclusions}

These eight Lamiaceae plants are often used in many local dishes of Manipur, are strong free radical scavengers and can be considered as good sources of natural antioxidants for many dishes, medicinal and commercial utility. Although, the plants taken belong to same family Lamiaceae, each of them whether under same genus or same species has different concentration of phenolic compounds with varied flavonoids and tannin content leading to differing amounts of antioxidants. The use of plants, foods and herbal products as antioxidants is increasing due to consumer awareness of their various health benefits. So, the paper will provide data on natural antioxidant sources in family Lamiaceae which is found in Manipur. However, further research is needed for isolation and identification of the phenolic compounds, flavonoids and tannins.

\section{Acknowledgements}

Authors are thankful to UGC, New Delhi for providing financial assistance to Sandhyarani D. Khomdram for her research programme as SRF/NET. We are also grateful to the Head, Centre for Advanced Study in Life Sciences for providing facilities during the research programme.

\section{References}

Akiyama H, Fujii K, Yamasaki O, Oono T, Iwatsuki K (2001). Antibacterial action of several tannins against Staphylococcus aureus. J Antimicrob Chemother 48(4):487-91.

Antolovich M, Prenzler PD, Patsalides E, McDonald S, Robards K (2002). Methods for testing antioxidant activity. Analyst 127:183-198.

Atanassova M, Christova-Bagdassarian V(2009).Determination of tannin content by titrimetric method for comparison of different plant species. Journal of the University of Chemical Technology and Metallurgy 44(4):413-415.

Chang C, Yang M, Wen H, Chern J (2002). Estimation of total flavonoid content in propolis by two complementary colorimetric methods. J Food Drug Anal 10:178-182.

Chang H, Huang G, Agrawal DC, Kuo C, Wu C, Tsay H (2007). Antioxidant activities and polyphenol contents of six folk medicinal ferns used as "Gusuibu". Botanical Studies 48:397-406.

Chen JH, Ho C (1997). Antioxidant activities of caffeic acid and its related hydrocinnamic acid compounds. J Agric Food Chem 45:2374-2378.

Cotelle N (2001). Role of flavonoids in oxidative stress. Curr Top Med Chem 1:569-590.

Devi KS, Devi YS, Singh PK (2008). Floristic distribution of an invasive weed Hyptis suaveolens Poit. in the valley districts of Manipur. Indian J Environ Ecoplan 15(1-2):177-180.

Dudonne S, Vitrac X, Coutiere P, Woillez M, Merillon J (2009). Comparative study of antioxidant properties and total $\mathrm{M}$ phenolic content of 30 plant extracts of industrial interest using DPPH, ABTS, FRAP, SOD, and ORAC assays. J Agric Food Chem 57:1768-1774.

Edeoga HO, Omosun G, Uche LC (2006). Chemical composition of Hyptis suaveolens and Ocimum gratissimum hybrids from Nigeria. African Journal of Biotechnology 5(10):892-895.

Facino RM, Carini M, Franzoi L, Pirola O, Bosisio E (1990). Phytochemical characterization and radical scavenger activity of flavonoids from Helichrysum italicum G. Don (Compositae). Pharmacol Res 22:709-721.

Hakkim FL, Arivazhagan G, Boopathy R (2008). Antioxidant property of selected Ocimum species and their secondary metabolite content. Journal of Medicinal Plants Research 
2(9):250-257.

Harborne JB (1988). Introduction to ecological biochemistry $3^{\text {rd }}$ edn, Academic Press London.

Harley RM, Atkins S, Budantsev AL, Cantino PD, Conn BJ, Grayer R, Harley MM, de Kok R, Krestovskaja T, Morales R, Paton AJ, Ryding O, Upson T (2004). Labiatae, p. 167 282. In: Kadereit JW (Ed.). The families and genera of vascular plants. Vol. VII, Lamiales. Berlin: Springer.

Hirasa K, Takemasa M (1998). Spice science and technology. Marcel Dekker: New York.

King-Thom C, Wong TY, Cheng IW, Yao-Wen H, Yuan L (1998). Tannins and Human Health: A Review Crit Rev Food Sci 38:421-468.

Lachance PA, Nakat Z, Jeong WS (2001). Antioxidants: an integrative approach. Nutrition 17:835-838.

Lu L, Liu SW, Jiang SB, Wu SG (2004). Tannin inhibits HIV1 entry by targeting gp 41. Acta Pharmacol Sin 25(2):213218.

Marinova EM, Yanishlieva NV (1997). Antioxidative activity of extracts from selected species of the family Lamiaceae in sunflower oil. Food Chem 58:245-248.

Meyers N, Mittermeier RA, Mittermeier CG, Fonseca GAB, Kent J (2000). Biodiversity hotspots for conservation priorities. Nature 403:853-858.

Miyazawa M, Okuno Y, Nakamura S, Kosaka H (2000). Antimutagenic activity of flavonoids from Pogostemon cablin. J Agric Food Chem 48:642-647.

Naik GH, Priyadarsini KI, Mohan H (2006). Free radical scavenging reactions and phytochemical analysis of triphala, an ayurvedic formulation. Current Science 90(8):11001105.

Nickavar B, Kamalinezad M, Izadpanah H (2007). In vitro free radical scavenging activity of five Salvia species. Pak J Pharm Sci 20(4):291-294.

Pandhair V, Shekhon BS (2006). Reactive oxygen Species and antioxidants in plants: An Overview. J Plant Biochemistry Biotechnology 15:71-78.

Parshad R, Sanford KK, Price FM, Steele VE, Tarone RE, Kelloff GJ, Boone CW (1998). Protective action of plant polyphenols on radiation-induced chromatid breaks in cultured human cells. Anticancer Res 18:3263-3266.

Ramakrishnan K, Selvi SR, Shubha R (2006). Tannin and its analytical technique. Indian Chemical Engr 48(2):88-93.
Rasineni GK, Siddavattam D, Reddy AR (2008). Free radica quenching activity and polyphenols in three species of Coleus. Journal of Medicinal Plants Research 2(10):285291.

Rice-Evans CA, Miller NJ, Paganga G (1997). Antioxidant properties of phenolic compounds. Trends Plant Sci 2:152159.

Shui GH, Leong LP (2004). Analysis of polyphenolic antioxidants in star fruit using liquid chromatography and mass spectrometry. J Chromatogr A: 1022:67-75.

Tanimura S, Kadomoto R, Tanaka T, Zhang YJ, Kouno I, Kohno M (2005). Suppression of tumor cell invasiveness by hydrolysable tannins (plant polyphenols) via the inhibition of matrix metalloproteinase-2/-9 activity. Biochem Biophys Res Commun 330(4):1306-1313.

Thimmaiah SR (1999). Standard Methods of Biochemical Analysis. Kalyani Publishers, New Delhi-110002.

Triantaphyllou K, Blekas G, Boskou D (2001). Antioxidative properties of water extracts obtained from herbs of the species Lamiaceae. Int J Food Sci Nutri 52:313-317.

Veglioglu, YS, Mazza G, Gao I, Oomah BD (1998). Antioxidant activity and total phenolics in selected fruits, vegetables and grain products. J Agric Food Chem 46:4113-4117.

Wolfe K, Wu X, Liu RH (2003). Antioxidant activity of apple peels. J Agric Food Chem 51:609-614.

Yang B, Kotani A, Arai K, Kusu F (2001). Estimation of the antioxidant activities of flavonoids from their oxidation potentials. Anal Sci 17:599-604.

Yang D, Wang Q, Ke L, Jiang J, Ying T (2007). Antioxidant activities of various extracts of lotus (Nelumbo nucifera Gaertn.) rhizome. Asia Pac J Clin Nutr 16:158-163.

Yang LL, Lee CY, Yen KY (2000). Induction of apoptosis by hydrolyzable tannins from Eugenia jambos L. on human leukemia cells. Cancer Lett 157(1):65-75.

Zhu YZ, Huang SH, Tan BKH, Sun J, Whiteman M, Zhu YC (2004). Antioxidants in Chinese herbal medicines: a biochemical perspective. Nat Prod Rep 21:478-489. 